\title{
Erratum to: A new approach for the geological risk evaluation of coal resources through a geostatistical simulation
}

\section{Case study: Parvadeh III coal deposit}

\author{
Omid Asghari • Nasser Madani Esfahani
}

Published online: 9 January 2014

(C) Saudi Society for Geosciences 2014

Erratum to: Arab J Geosci (2013) 6:929-943

DOI 10.1007/s12517-011-0391-7

The original version of this article, unfortunately, contained an error.

The family name of the first author, Omid Asghari, was incorrectly spelled in the original article. His correct name is given in this paper.

The online version of the original article can be found at http://dx.doi.org/ 10.1007/s12517-011-0391-7.

O. Asghari $(\bowtie)$

Department of Mining Engineering, University of Tehran, Tehran, Iran

e-mail: O.Asghari@ut.ac.ir

N. M. Esfahani

Young Researchers Club, South Tehran Branch, Islamic Azad

University, Tehran, Iran

e-mail: N_Madani@azad.ac.ir 